\title{
DEVELOPMENT OF PIGEON PEA INOCULATED WITH RHIZOBIUM ISOLATED FROM COWPEA TRAP HOST PLANTS ${ }^{1}$
}

\author{
SALOMÃO LIMA GUIMARÃES ${ }^{2 *}$, LAURA CRISTINA REZENDE DAS NEVES² ${ }^{2}$ EDNA MARIA BONFIM-SILVA², \\ DANIELA TIAGO DA SILVA CAMPOS ${ }^{3}$
}

\begin{abstract}
Pigeon pea is an important protein source grown in several tropical and sub-tropical countries, and is considered a multi-purpose plant that is resistant to the conditions of the Brazilian Cerrado. Among the possible uses for cowpea, its use as a green manure, increasing soil nitrogen content through the association with diazotrophic bacteria, generically known as rhizobia, is noteworthy. The present work aimed to evaluate the efficiency of Rhizobium strains isolated from cowpea plants in the development of pigeon peas cultured in Red Latosol. The experiment was conducted in a greenhouse, using a completely randomized design with seven treatments and four replications. Treatments consisted of inoculation with four Rhizobium strains (MT8, MT15, MT16, and MT23) and one commercial inoculant comprising Bradyrhizobium spp. strains BR 2801 and BR 2003. There were two controls, one absolute (without inoculation or nitrogen fertilization) and the other with nitrogen fertilization. Each experimental plot consisted of an $8-\mathrm{dm}^{3}$ vase containing three plants. Analyzed variables included plant height, SPAD index, number and dry weight of nodules, and shoot and root dry masses. Pigeon peas responded significantly to inoculation treatment, since all the plants inoculated with Rhizobium strains isolated from cowpea strains showed results similar to plants in the nitrogen control and commercial inoculant treatments. This demonstrates a favorable plant-bacteria interaction, which can be utilized as an alternative nitrogen source for pigeon peas.
\end{abstract}

Keywords: Cajanus cajan. Cerrado. Inoculation.

\section{DESENVOLVIMENTO DO FEIJÃO GUANDU INOCULADO COM RIZÓBIO ISOLADO DE PLANTAS ISCAS DE FEIJÃO CAUPI}

RESUMO - O feijão guandu é uma importante fonte proteica usada em diversos países dos trópicos e subtrópicos, sendo considerada uma planta de múltiplos usos e resistente às condições do Cerrado brasileiro. Dentre as atividades utilizadas, destaca-se o emprego como adubo verde, promovendo aumento do teor de nitrogênio no solo através da associação com bactérias diazotróficas genericamente conhecidas como rizóbio. Este trabalho teve por objetivo avaliar a eficiência de estirpes de rizóbio isoladas de plantas de feijão caupi sobre o desenvolvimento do feijão guandu cultivado em Latossolo Vermelho. O experimento foi conduzido em casa de vegetação, em delineamento experimental inteiramente casualizado com sete tratamentos e quatro repetições. Os tratamentos foram constituídos de cinco estirpes de rizóbio (MT8, MT15, MT16, MT23, um inoculante comercial composto pelas estirpes BR 2801 e BR 2003 de Bradyrhizobium spp.) e duas testemunhas, sendo uma absoluta (sem inoculação e sem adubação nitrogenada) e outra com adubação nitrogenada. Cada parcela experimental foi composta por um vaso de $8 \mathrm{dm}^{3}$, contendo três plantas. As variáveis analisadas foram altura de plantas, índice SPAD, número e massa seca de nódulos e massa seca da parte aérea e das raízes. O feijão guandu respondeu significativamente aos tratamentos com inoculação, onde todas as estirpes isoladas de feijão caupi apresentaram resultados semelhantes à testemunha nitrogenada e ao inoculante comercial, demonstrando uma favorável interação planta-bactéria, podendo ser uma alternativa para o fornecimento do nitrogênio requerido pelo feijão guandu.

Palavras-chave: Cajanus cajan. Cerrado. Inoculação.

\footnotetext{
*Corresponding author

${ }^{1}$ Received for publication in $06 / 18 / 2014$; accepted in $05 / 30 / 2016$.

Paper extracted from the monograph of the Agricultural Engineering and Environmental Course of the second author.

${ }^{2}$ Department of Agricultural and Environmental Engineering, Universidade Federal de Mato Grosso, Rondonópolis, MT, Brazil; slguimaraes@ufmt.br, lauracristina_rezende@hotmail.com,embonfim@hotmail.com.

${ }^{3}$ Faculty of Agronomy, Universidade Federal de Mato Grosso, Cuiabá, MT, Brazil; camposdts@yahoo.com.br.
} 


\section{INTRODUCTION}

Concern about environmental issues has generated much discussion in the agricultural sector. The lack of preservation practices and inadequate soil handling are causing fertility problems, leading to the degradation of existing areas and opening of new areas, thereby causing negative environmental impacts (POTT et al., 2007).

The loss of soil fertility leads to nutrient deficiency, including that of nitrogen, which is essential for crop development (GUARESCHI; GAZOLLA; ROCHA, 2011). Mineral nitrogen is an input that, when improperly used, can cause diverse environmental damage. Its proper use is important to reduce both production costs and environmental pollution levels (GUIMARÃES et al., 2010).

Green manure has been proposed as an alternative to minimize these problems, as this preservation practice greatly benefits the productive system in a number of ways, including land coverage and protection; maintenance or improvement of physical, chemical, and biological soil conditions; growth of macro- and microorganisms in depth in soil; and possible use of the produced biomass for animal feed or other purposes (CALEGARI et al., 1993).

Pigeon pea (Cajanus cajan) is a plant that is resistant to adverse climate and soil conditions, such as those found in the Brazilian Cerrado, and is used in soil improvement, recovery of degraded land, phytoremediation, pasture renovation, as a forage, and for human consumption (AZEVEDO; CARVALHO; MARQUES, 2008; PROVAZI; CAMARGO; GODOY, 2007). This plant also has a high biomass-producing capacity, being able to yield up to $11 \mathrm{t} \mathrm{ha}^{-1}$ and contributing to the incorporation of $\mathrm{N}$ and $\mathrm{P}$ (283 kg ha ${ }^{-1}$ and $23 \mathrm{~kg} \mathrm{ha}^{-1}$, respectively) (ALVES et al., 2004).

According to Soussi et al. (2001), even though pigeon pea exhibits high symbiotic capacity with autochthonous bacteria, generally known as rhizobia, its agricultural output may be limited; thus, it is necessary to inoculate this plant with strains that are efficient in enhancing its production. The efficiency of this symbiosis might, however, be affected not only by bacterial strain and plant cultivar, but also by environmental conditions (FERREIRA et al., 2012).

Thus, the present study aimed to evaluate the effect of Rhizobium strains isolated from cowpea plants on the development of pigeon pea grown in Red Latosol.

\section{MATERIAL AND METHODS}

The experiment was conducted in a greenhouse at the Federal University of Mato
Grosso, Rondonópolis Campus.

The soil used in the experiment was Red Latosol (EMBRAPA, 2006), collected in a native Cerrado area at a depth of $0-20 \mathrm{~cm}$, and stored in $8-\mathrm{dm}^{3}$ vases. The results of soil analyses were as follows: $\mathrm{pH}\left(\mathrm{CaCl}_{2}\right): 4.2$; P: $3.2 \mathrm{mg} \mathrm{dm}^{-3} ; \mathrm{K}: 60 \mathrm{mg}$ $\mathrm{dm}^{-3}$; Ca: 0.3 cmolc dm $\mathrm{dm}^{-3}$ Mg: 0.2 cmolc $\mathrm{dm}^{-3} ; \mathrm{Al}$ : 1.0 cmolc dm ${ }^{-3} ; \mathrm{H}^{+} \mathrm{Al}: 6.1$ cmolc $\mathrm{dm}^{-3}$; cation exchange capacity: 6.8 ; and $\mathrm{V}(\%)$ : 9.6. The soil was not sterilized by autoclaving in order to maintain conditions similar to those of the natural environment.

Liming was performed using dolomitic limestone with $80.3 \%$ relative total neutralizing power (RTNP), considering a $60 \%$ base saturation, which was allowed to react for a period of 30 days to correct acidity. During this period, soil moisture was maintained at $60 \%$ of its maximum water retention using a gravimetric method; maximum water retention had previously been determined in triplicate in the laboratory, using vases with identical volume to those used in the present experiment (BONFIM-SILVA et al., 2011).

After the limestone incubation period, fertilization was carried out by applying phosphorus (200 $\mathrm{mg} \mathrm{dm}^{-3}$, simple superphosphate as source),

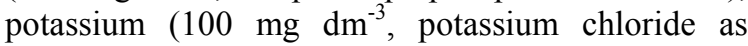
source), and micronutrients (a mixture of boric acid, $1.0 \mathrm{mg} \mathrm{dm}{ }^{-3}$; copper chloride, $1.0 \mathrm{mg} \mathrm{dm}{ }^{-3}$; zinc chloride, $3.0 \mathrm{mg} \mathrm{dm}^{-3}$; and sodium molybdate, 0.2 $\mathrm{mg} \mathrm{dm}^{-3}$ as sources) (SOUZA; LOBATO, 2002).

The experimental design was completely randomized with seven treatments and four replications, for a total of 28 plots. The treatments consisted of inoculation with four Rhizobium strains [MT8, MT15 (Rhizobium tropici), MT16, and MT23 (R. leguminosarum)], isolated from cowpea trap host plants (BRS Novaera cultivar) and deposited in the Environment Laboratory of the Institute of Agricultural Sciences and Technology of the Universidade Federal de Mato Grosso and inoculation with a commercial inoculant recommended for pigeon pea (comprising a combination of Bradyrhizobium spp. strains BR 2801 and BR 2003). Two controls were used, one absolute (with neither inoculation nor nitrogen fertilization) and one without inoculation but with urea as a nitrogen $\left(50 \mathrm{mg} \mathrm{dm}^{-3}\right)$ source.

BRS Mandarim was the pigeon pea cultivar used, as it is adapted to the regional conditions. Ten seeds were sown per pot, and 5 days after seedling emergence, thinning was performed so as to leave three plants.

Plant height and SPAD (Soil Plant Analysis Development) index were evaluated 30, 60, 90, and 117 days after emergence (DAE) using a chlorophyll meter. The assessment was performed using two leafs in the middle third of each plant. The number and dry mass of nodules, shoots, and roots were evaluated at 117 DAE. Dry masses were determined 
after placing nodules, roots, and shoots in a forced-air circulation oven at $65^{\circ} \mathrm{C}$ for 72 hours, or until reaching constant mass.

Statistical analysis was performed using the statistical software SISVAR 4.2 (FERREIRA, 2008). The data were submitted to analysis of variance, and mean values of each treatment were compared using Tukey's test at the 5\% probability level.

\section{RESULTS AND DISCUSSION}

The first evaluation was performed at 30 DAE. No significant difference was found in plant height when comparing the different treatments. Plants with greater height had, nevertheless, been inoculated with the MT23 strain. However, at 60, 90, and 117 DAE, significant responses were observed (Table 1).

Table 1. Pigeon pea plant height as a function of inoculation with Rhizobium strains isolated from cowpea.

\begin{tabular}{lcccr}
\hline \multirow{2}{*}{ Treatments } & \multicolumn{3}{c}{ Evaluation periods (DAE) } \\
\cline { 2 - 4 } & 30 & 60 & 90 & 117 \\
\hline MT8 & $17.25^{\mathrm{ns}}$ & $41.25 \mathrm{a}$ & $78.13 \mathrm{a}$ & $90.00 \mathrm{a}$ \\
MT15 & 14.50 & $38.25 \mathrm{a}$ & $71.88 \mathrm{a}$ & $83.25 \mathrm{a}$ \\
MT16 & 17.50 & $39.00 \mathrm{a}$ & $76.00 \mathrm{a}$ & $86.50 \mathrm{a}$ \\
MT23 & 22.25 & $43.50 \mathrm{a}$ & $81.63 \mathrm{a}$ & $94.00 \mathrm{a}$ \\
Commercial Inoculant & 20.25 & $45.50 \mathrm{a}$ & $82.13 \mathrm{a}$ & $89.00 \mathrm{a}$ \\
Nitrogen control & 18.25 & $42.25 \mathrm{a}$ & $77.25 \mathrm{a}$ & $27.50 \mathrm{~b}$ \\
Absolute control & 15.00 & $18.75 \mathrm{~b}$ & $27.75 \mathrm{~b}$ & 10.29 \\
\hline CV (\%) & 19.51 & 9.84 & 9.23 & \\
\hline
\end{tabular}

Means followed by different letters differ significantly, as determined by the Tukey's test at the $1 \%$ probability level. ns - not significant

From the second evaluation onwards $(60,90$, and $117 \mathrm{DAE})$, all strains performed similarly to the commercial inoculant and nitrogenated control. These results corroborate the findings of Lima et al. (2011), who also found no significant difference in plant height between inoculation treatments. This indicates the efficiency of the pigeon pea-rhizobia symbiosis in supplementing nitrogen, enabling plants to develop in a manner similar to those fertilized with nitrogen (FERREIRA et al., 2000). This further highlights the importance of biological nitrogen fixation (BNF) in the growth and development of leguminous and non-leguminous plants (BALDANI et al., 2005; FERREIRA et al., 2010; GUIMARÃES; BALDANI; JACOB-NETO, 2013).

The SPAD index is an important parameter used in the evaluation of plant development, as it provides values that are correlated with the chlorophyll content in leaves, enabling diagnosis of plant nutritional status in relation to nitrogen (AMARAL FILHO et al., 2005).

In the present study, there were significant differences between the SPAD index values in all evaluations (Table 2).

The most significant SPAD index values at 30 DAE were observed in plants fertilized with nitrogen and treated with the MT8 strain. At the $60 \mathrm{DAE}$ evaluation, plants inoculated with the MT8, MT16, and MT23 strains and the commercial inoculant, and also the nitrogen control plants, were performing well, although in a manner similar to plants inoculated with the MT15 strain, for which the SPAD index value was similar to that for the absolute control.

At 90 DAE, only MT23-inoculated plants exhibited SPAD index values higher than those of the absolute control. In the final evaluation, carried out at 117 DAE (the period in which the flowers started to bloom), only plants inoculated with the commercial inoculant and the MT8 and MT23 strains showed higher SPAD index values than those of the absolute control.

According to Souza; Soratto, and Pagani (2010), a nitrogen increase in coverage contributes to nitrogen content and accumulation in the shoot, which is consistent with the observed SPAD index values of inoculated plants and plants fertilized with nitrogen. In the former plants, symbiosis with rhizobia strains yielded good results with respect to nitrogen status, since there is a strong correlation between chlorophyll values and nitrogen concentration in leaves (DIDONET; BRAZ; SILVEIRA, 2005; SILVA et al., 2010). 
Table 2. Pigeon pea SPAD index as a function of inoculation with Rhizobium strains isolated from cowpea.

\begin{tabular}{|c|c|c|c|c|}
\hline \multirow{2}{*}{ Treatments } & \multicolumn{3}{|c|}{ Evaluation periods (DAE) } & \multirow[b]{2}{*}{117} \\
\hline & 30 & 60 & 90 & \\
\hline MT8 & $46.75 \mathrm{a}^{* *}$ & $50.25 \mathrm{a}^{* *}$ & $54.25 \mathrm{ab}^{*}$ & $55.50 \mathrm{a}^{* *}$ \\
\hline MT15 & $42.00 \mathrm{ab}$ & $45.00 \mathrm{ab}$ & $50.75 \mathrm{ab}$ & $51.00 \mathrm{ab}$ \\
\hline MT16 & $45.25 \mathrm{ab}$ & $45.50 \mathrm{a}$ & $48.50 \mathrm{ab}$ & $51.75 \mathrm{ab}$ \\
\hline MT23 & $45.00 \mathrm{ab}$ & $50.50 \mathrm{a}$ & $57.00 \mathrm{a}$ & $55.65 \mathrm{a}$ \\
\hline Commercial inoculant & $40.75 \mathrm{ab}$ & $49.00 \mathrm{a}$ & $53.50 \mathrm{ab}$ & $54.73 \mathrm{a}$ \\
\hline Nitrogen control & $49.00 \mathrm{a}$ & $50.00 \mathrm{a}$ & $51.00 \mathrm{ab}$ & $49.75 \mathrm{ab}$ \\
\hline Absolute control & $37.75 \mathrm{~b}$ & $36.50 \mathrm{~b}$ & $45.00 \mathrm{~b}$ & $47.25 \mathrm{~b}$ \\
\hline CV (\%) & 8.73 & 8.33 & 8.35 & 5.96 \\
\hline
\end{tabular}

Means followed by different letters are significantly different, as determined by the Tukey test at $1 \%(* *)$ and $5 \%(*)$ probability levels.

Araújo et al. (2007) observed that in common bean plants the highest concentration of nitrogen occurred in plants inoculated with a commercial inoculant and fertilized with nitrogen, corroborating the findings of Ferreira et al. (2000), who demonstrated that nitrogen fertilization and the establishment of a symbiosis resulted in increased nitrogen content in leaves, highlighting the importance of BNF for the common bean plant.

Using the natural ${ }^{15} \mathrm{~N}$ abundance technique,
Moreira et al. (2003) observed that $59 \%$ of the nitrogen present in pigeon pea shoots originated from $\mathrm{BNF}$, indicating the great potential of this species to provide nitrogen for its development, regardless of this element's availability in the soil.

The number and dry mass of nodules showed significant differences between the treatments (Table 3). All inoculation treatments were similar to the nitrogen control for these variables, and differed only from the absolute control.

Table 3. Number and dry mass of pigeon pea plant nodules as a function of inoculation with Rhizobium strains isolated from cowpea.

\begin{tabular}{ccc}
\hline Treatments & Number of nodules ${ }^{*}$ & Dry mass of nodules $^{*}$ \\
MT8 & $17.23 \mathrm{a}$ & $1.80 \mathrm{a}$ \\
MT15 & $19.05 \mathrm{a}$ & $1.58 \mathrm{a}$ \\
MT16 & $17.69 \mathrm{a}$ & $1.57 \mathrm{a}$ \\
MT23 & $17.70 \mathrm{a}$ & $1.68 \mathrm{a}$ \\
Commercial inoculant & $16.21 \mathrm{a}$ & $1.68 \mathrm{a}$ \\
Nitrogen control & $17.05 \mathrm{a}$ & $1.67 \mathrm{a}$ \\
Absolute control & $2.03 \mathrm{~b}$ & $1.00 \mathrm{~b}$ \\
\hline CV $(\%)$ & 23.10 & 7.82 \\
\hline
\end{tabular}

Mean values followed by different letters are significantly different, as determined by the Tukey test at the $1 \%$ probability level.

* - Data transformed to the square root of $\mathrm{Y}+1$ 
The number of nodules did not differ between strain-inoculation and nitrogen fertilization treatments. These results corroborate those of Lacerda et al. (2004), Soares et al. (2006), and Zilli et al. (2011), who obtained promising results using BNF inoculants in cowpea. Root nodulation allows plants to supplement nitrogen demand, required for their development and increase in biomass (HUNGRIA; VARGAS, 2000).

According to Xavier et al. (2006), parameters related to the number and mass of nodules are the criteria used to evaluate the Rhizobium-legume symbiosis, and are part of the protocol devised by the
Network of Laboratories for Recommendation, Standardization, and Dissemination of Microbial Inoculant Technologies of Agricultural Interest (RELARE) to evaluate the agronomic efficiency of strains in Brazil. For crops with green manure potential, their biomass production capacity is correlated with their contribution to improving the physical, chemical, and biological properties of soil.

A further aspect monitored when evaluating the efficiency of a Rhizobium strain is the production of dry mass. In the present study, there was a significant effect of treatment on shoot and root dry masses (Table 4).

Table 4. Pigeon pea plant shoot and root dry masses as a function of inoculation with Rhizobium strains isolated from cowpea.

\begin{tabular}{ccc}
\hline Treatments & Shoot dry mass $(\mathrm{g})$ & Root dry mass $(\mathrm{g})$ \\
MT8 & $46.90 \mathrm{a}$ & $22.00 \mathrm{a}$ \\
MT15 & $42.64 \mathrm{a}$ & $18.34 \mathrm{a}$ \\
MT16 & $39.23 \mathrm{a}$ & $16.75 \mathrm{a}$ \\
MT23 & $43.88 \mathrm{a}$ & $22.40 \mathrm{a}$ \\
Commercial inoculant & $48.00 \mathrm{a}$ & $23.90 \mathrm{a}$ \\
Nitrogen control & $50.42 \mathrm{a}$ & $24.29 \mathrm{a}$ \\
Absolute control & $2.25 \mathrm{~b}$ & $1.00 \mathrm{~b}$ \\
\hline CV $(\%)$ & 13.78 & 26.64 \\
\hline
\end{tabular}

Mean values followed by different letters are significantly different, as determined by the Tukey test at the $1 \%$ probability level.

Rhizobium strains isolated from cowpea showed no difference in relation to the commercial inoculant and nitrogen controls, indicating that the symbiosis between these strains and pigeon pea can fix atmospheric nitrogen and partially provide for the plant needs, enabling development similar to that of plants fertilized with nitrogen (FERREIRA et al., 2000). Similar findings have also been described in other studies involving crops such as soybean (SOUZA et al., 2008) and cowpea (XAVIER et al., 2007).

Root growth follows a species-characteristic pattern and is correlated with shoot growth. Moreover, there is a tendency for the root/shoot ratio to remain within a certain range (BONFIM-SILVA et al., 2011). The ability of rooting to greater depths shows the potential of pigeon pea to exploit deeper soil layers for water absorption and nutrient recycling (AZEVEDO; CARVALHO, MARQUES, 2008; SOUTO et al., 2009), which makes it an interesting crop for the production of grains used for food, for recovery of degraded areas, and as a green manure.

\section{CONCLUSION}

Rhizobium strains isolated from cowpea trap host plants have the potential to be used as pigeon pea inoculants, to participate in a favorable plant-bacterium interaction, and can tentatively serve as a source for green manure.

\section{REFERENCES}

ALVES, S. M. C. et al. Balanço do nitrogênio e fósforo em solo com cultivo orgânico de hortaliças após a incorporação de biomassa de guandu. Pesquisa Agropecuária Brasileira, Brasília, v. 39, n. 11, p. 1111-1117, 2004.

AMARAL FILHO, J. P. R. et al. Espaçamento, densidade populacional e adubação nitrogenada na cultura do milho. Revista Brasileira de Ciência do Solo, Viçosa, v. 29, n. 1, p. 467-473, 2005. 
ARAÚJO, F. F. et al. Fixação biológica de $\mathrm{N}_{2}$ no feijoeiro submetido a dosagens de inoculante e tratamento químico na semente comparado à adubação nitrogenada. Acta Scientiarum. Agronomy, Maringá, v. 29, n. 1, p. 540-540, 2007.

AZEVEDO, R. L.; CARVALHO, C. A. L.; MARQUES, O. M. Insetos associados à cultura do feijão guandu na região do Recôncavo da Bahia, Brasil. Revista Caatinga, Mossoró, v. 21, n. 4, p. 83-88, 2008.

BALDANI, V. L. D.; BALDANI, J. I. History on the biological nitrogen fixation research in graminaceous plants: special emphasis on the Brazilian experience. Anais da Academia Brasileira de Ciências, Rio de Janeiro, v. 77, n. 3, p. 549-579, 2005

BONFIM-SILVA, E. M. et al. Leguminosa híbrida submetida à calagem em LATOSSOLO Vermelho do Cerrado. Enciclopédia Biosfera, Goiânia, v. 7, n. 13, p. 1811-1820, 2011

CALEGARI, A. et al. Aspectos gerais de adubação verde. Adubação verde no sul do Brasil. 1. ed. Rio de Janeiro, RJ: ASPTA, 1993. 55 p.

DIDONET, A. D.; BRAZ, A. J. B. P.; SILVEIRA, P. M. Adubação nitrogenada de cobertura no feijoeiro irrigado: uso do clorofilometro. Bioscience Journal, Uberlândia, v. 21, n. 9, p. 103-111, 2005.

SANTOS, H. G. et al. Sistema brasileiro de classificação de solos. 2. ed. Brasília, DF: EMBRAPA, 2006. 306 p.

FERREIRA, A. N. et al. Estirpes de Rhizobium Tropici na inoculação do feijoeiro. Scientia Agricola, Piracicaba, v. 57, n. 3, p. 507-512, 2000.

FERREIRA, D. F. SISVAR: um programa para análise e ensino de estatística. Revista Symposium, Recife, v. 6, n. 1, p. 36-41, 2008.

FERREIRA, J. S.; BALDANI, J. I.; BALDANI, V. L. D. Seleção de inoculantes à base de turfa contendo bactérias diazotróficas em duas variedades de arroz. Acta Scientiarum Agronomy, Maringá, v. 32 , n. 1 , p. $179-185,2010$.

FERREIRA, P. A. A. et al. Efficient nitrogen-fixing Rhizobium strains isolated from amazonian soils are highly tolerant to acidity and aluminium. World Journal Microbiology Biotechnology, Dordrecht, v. 28, n. 1, p. 1947- 1959, 2012.

GUARESCHI, R. F. et al. Nodulação e crescimento vegetativo de feijão azuki (Vigna angularis) submetido a inoculação e adubação nitrogenada.
Global Science and Technology, Rio Verde, v. 4, n. 3, p. $75-82,2011$

GUIMARÃES, S. L.; BALDANI, V. L. D.; JACOB-NETO, J. Viabilidade do inoculante turfoso produzido com bactérias associativas e molibdênio. Revista Ciência Agronômica, Fortaleza, v. 44, n. 1, p. 10-15, 2013.

GUIMARÃES, S. L. et al. Bactérias diazotróficas e adubação nitrogenada em cultivares de arroz. Revista Caatinga, Mossoró, v. 23, n. 4, p. 32-39, 2010 .

HAFEEZ, F. Y. et al. A. Rhizobial inoculation improves seedling emergence, nutrient uptake and growth of cotton. Australian Journal of Experimental Agriculture, Collingwood, v. 44, n. 6, p. 617-622, 2004.

HUNGRIA, M; VARGAS, M. A. T. Environmental factors affecting $\mathrm{N}_{2}$ fixation in grain legumes in the tropics, with an emphasis on Brazil. Field Crops Research, Amsterdam, v. 65, n. 2, p. 151-164, 2000.

LACERDA, A. M. et al. Efeito de estirpes de rizóbio sobre a nodulação e produtividade do feijão-caupi. Revista Ceres, Viçosa, v. 51, n. 1, p. 67-82, 2004.

LIMA, A. S. T. et al. Sinergismo Bacillus brevibacillus e, ou, Paenibacillus na simbiose Bradyrhizobium-caupi. Revista Brasileira de Ciência do Solo, Viçosa, v. 35, n. 3, p. 713-721, 2011.

MOREIRA, V. et al. Produção de biomassa de guandu em função de diferentes densidades $e$ espaçamentos entre sulcos de plantio. 1. ed. Seropédica: EMBRAPA, 2003. 5 p. (Comunicado técnico, 57)

PIMENTEL, C. Metabolismo de carbono na agricultura tropical. Seropédica, RJ: EDUR, 1998. $150 \mathrm{p}$.

POTT, C. A. et al. Adubação verde como alternativa agroecológica para recuperação da fertilidade do solo. Ambiência - Revista do Setor de Ciências Agrárias e Ambientais, Guarapuava, v. 3, n. 1, p. 51-63, 2007.

PROVAZI, M. et al. Descrição botânica de linhagens puras selecionadas de guandu. Revista Brasileira de Zootecnia, Viçosa, v. 36, n. 2, p. 328-334, 2007.

SILVA, E. F. L. et al. Fixação Biológica do $\mathrm{N}_{2}$ em feijão-caupi sob diferentes doses e fontes de fósforo solúvel. Bioscience Journal, Uberlândia, v. 26, n. 3, p. 394-402, 2010. 
SOARES, A. L. L. et al. Eficiência agronômica de rizóbios selecionados e diversidade de populações nativas nodulíferas em Perdões (MG). I - Caupi. Revista Brasileira de Ciência do Solo, Viçosa, v. 30, n. 5, p. 795-802, 2006.

SOUSA, D. M. G.; LOBATO, E. Adubação fosfatada em solos da região do Cerrado. 1. ed. Piracicaba: Potafos, 2002. 16 p. (Informações Agronômicas, 102).

SOUSSI, M. et al. Effects of salinity on protein and lipopocacharide pattern in a salt - tolerant strain of Mesorhizobium cicero. Journal of Applied Microbiology, Bedford, v. 90, n. 1, p. 476-481, 2001.

SOUTO, J. S. et al. Efeito da aplicação de fósforo no desenvolvimento de plantas de feijão-guandu (Cajanus cajan (L.) Millsp.), Revista Verde, Mossoró, v. 4, n. 1, p. 135, 2009.

SOUZA, R. A. et al. Conjunto mínimo de parâmetros para avaliação da microbiota do solo e da fixação biológica de nitrogênio pela soja. Pesquisa Agropecuária Brasileira, Brasília, v. 43, n. 1, p. 83-91, 2008.

SOUZA, E. F. C.; SORATTO, R. P.; PAGANI, F. A. Aplicação de nitrogênio e inoculação com rizóbio em feijoeiro cultivado após milho consorciado com braquiária. Pesquisa Agropecuária Brasileira, Brasília, v. 46, n. 4, p. 370-377, 2010.

XAVIER, G. R. et al. Especificidade Simbiótica entre Rizóbios e acessos de Feijão-Caupi de Diferentes nacionalidades. Revista Caatinga, Mossoró, v. 19, n. 1, p. 25-33, 2006.

XAVIER, T. F. et al. Ontogenia da nodulação em duas cultivares de feijão-caupi. Ciência Rural, Santa Maria, v. 37, n. 2, p. 561-564, 2007.

ZILLI, J. E. et al. Resposta do feijão-caupi à inoculação com estirpes de Bradyrhizobium recomendadas para a soja. Revista Brasileira de Ciência do Solo, Viçosa, v. 35, n. 1, p. 739-742, 2011. 